\title{
Detection of activating mutations in the ras family genes in cytological specimens from lung tumours
}

\author{
H. KIARIS ${ }^{1,2}$, M. ERGAZAKI ${ }^{1,2}$, S. SAKKAS ${ }^{3}$, E. ATHANASIADOU ${ }^{3}$ and D.A. SPANDIDOS ${ }^{1,2}$ \\ ${ }^{1}$ Institute of Biological Research and Biotechnology, National Hellenic Research Foundation, \\ 48 Vas. Constantinou Avenue, Athens 116 35; ${ }^{2}$ Medical School, University of Crete, Heraklion; \\ ${ }^{3}$ Laboratory of Cytology, General Hospital of Nikeas, Pireas, Greece
}

Received May 10, 1995; Accepted June 17, 1995

\begin{abstract}
Mutations in the ras family genes (K-ras mainly) represent a common event in lung tumorigenesis which is frequently associated with poor clinical outcome. In order to investigate whether K-ras mutations are detectable in cytological material obtained from patients with lung cancer, 37 cytological specimens ( 16 fine needle aspiration and 21 bronchoscopy) were assessed for codon 12 point mutations in the $\mathrm{H}-, \mathrm{K}-$ and $\mathrm{N}$-ras genes by combined polymerase chain reaction-restriction fragment length polymorphism. K-ras codon 12 point mutations were found in 8 out of $37(22 \%)$ specimens while no mutations were found in the H-ras and $\mathrm{N}$-ras genes. Mutations were found in 27\% (3 out of 11) of adenocarcinomas while in squamous cell carcinomas the incidence of mutations was $18 \%$ ( 3 out of 17). In addition, a $\mathrm{K}$-ras codon 12 point mutation was found in one (12\%) among 8 small cell carcinomas and in the only Hodgkin's lymphoma with metastasis in the lung. Our results are in agreement with previous results that recognise high incidence of $\mathrm{K}$-ras activation in lung carcinomas, and indicate that detection of mutant ras alleles is possible in cytological material.
\end{abstract}

\section{Introduction}

The development of neoplasia requires specific genetic events targeting the activation of oncogenes and the inactivation of tumour suppressor genes (TSGs) (1). The ras family genes that encode for small GTPases of the plasma membrane, are frequently found activated in various human tumours. Activation of the ras family genes usually occurs by point mutations at codons 12,13 and 61 , abolishing from the mutant protein the property to exchange GTP with GDP and to remain constantly activated (2).

Correspondence to: Professor D.A. Spandidos, Institute of Biological Research and Biotechnology, National Hellenic Research Foundation, 48 Vas. Constantinou Avenue, Athens 116 35, Greece

Key words: ras mutations, lung cancer, cytological material, PCR-RFLP
Activated members of the ras family have been detected in approximately $90 \%$ of pancreatic and $40 \%$ of colorectal cancers (3). In lung tumours $30 \%$ of the specimens, mainly adenocarcinomas, harbour ras mutations. The mutations usually affect the $\mathrm{K}$-ras proto-oncogene, but $\mathrm{H}$-ras and $\mathrm{N}$-ras genes have also been found to harbour activating point mutations. Furthermore, lung tumours harbouring an activated member of the ras family, are characterised by poor clinical outcome, indicating an important role for the ras genes in the development of the disease (4-8).

A major problem in lung tumorigenesis is the late stage of the disease in which the tumour is detectable. The detection of particular molecular alterations, highly associated with the development of the disease, could serve as a molecular marker for the development of the tumour and help in the early detection of cancer.

In the present study, we evaluated the incidence of activated members of the ras family in cytological material obtained from patients with lung cancer. The detection of the mutant ras alleles was performed by a sensitive polymerase chain reaction-restriction fragment length polymorphism (PCR-RFLP) assay.

\section{Materials and methods}

Specimens. 37 cytological specimens (16 fine needle aspiration (FNA) and 21 bronchoscopy), consisting of 11 adenocarcinomas, 17 squamous cell carcinomas (SCC), 8 small cell carcinomas and one Hodgkin's lymphoma with metastasis in lung were obtained from the Department of Cytology, General Hospital of Nikeas, Pireas, Greece.

DNA extraction. Specimens were washed with 1X PBS buffer and DNA was extracted following standard proteinase $\mathrm{K}$ and phenol-chloroform extraction (9).

Polymerase chain reaction. Approximately $300 \mathrm{ng}$ of genomic DNA was amplified by the PCR in a $50 \mu$ reaction volume containing $500 \mu \mathrm{M}$ dNTPs, $30 \mathrm{pM}$ of each forward and reverse primer (10), $0.5 \mathrm{U}$ of Taq DNA polymerase and $5 \mu \mathrm{l}$ of $10 \mathrm{X}$ buffer $(670 \mathrm{mM}$ Tris. $\mathrm{HCl}, \mathrm{pH} 8.5 ; 166 \mathrm{mM}$ ammonium sulphate; $67 \mathrm{mM}$ magnesium chloride; $1.7 \mathrm{mg} / \mathrm{ml}$ BSA; $100 \mu \mathrm{M}, \beta$-mercaptoethanol and $1 \%(\mathrm{w} / \mathrm{v})$ Triton $\mathrm{X}-100$ ). PCR programs consisted of $95^{\circ} \mathrm{C}$ for $4 \mathrm{~min}$ and 35 cycles of $95^{\circ} \mathrm{C}, 57^{\circ} \mathrm{C}$ and $72^{\circ} \mathrm{C}$ for $40 \mathrm{sec}$ each step. 
Detection of ras mutations at codon 12 by restriction fragment length polymorphism (RFLP). PCR amplification of the ras genes surrounding codon 12 was performed as described above. $30 \mu \mathrm{l}$ of the PCR product was digested overnight with $20 \mathrm{U}$ of the restriction endonucleases MspI (H-ras) and Bst NI (K-ras and N-ras) in conditions recommended by the suppliers, electrophoresed in a $2 \%$ agarose gel (or $6 \%$ polyacrylamide gel for the $\mathrm{N}$-ras codon 12 ) and stained with ethidium bromide.

\section{Results}

In the present study we employed a combined PCR-RFLP assay in order to detect point mutations at codon 12 of $\mathrm{H}-, \mathrm{K}-$ and $\mathrm{N}$-ras genes in cytological material from patients with lung cancer (11 adenocarcinomas, 17 squamous cell carcinomas (SCC), 8 small cell carcinoma and one Hodgkin's lymphoma with metastasis in the lung). Our analysis revealed that 8 among $37(22 \%)$ specimens harboured a mutation at the K-ras gene (Table I, Fig. 1) while no mutations were found in the $\mathrm{H}$-ras and $\mathrm{N}$-ras genes, confirming previous reports (4-8) of higher incidence of mutations in lung cancer occuring in the K-ras gene.

The higher incidence of mutations was found in adenocarcinomas (3 out of $11,27 \%$ ). In SCC 3 out of 17 (18\%) specimens were found positive for a $\mathrm{K}$-ras point mutation. In addition, a K-ras codon 12 point mutation was found in a Hodgkin's lymphoma with metastasis in the lung (Table II). One (12.5\%) mutation was also found in 8 small cell carcinomas. No association was found between the presence of mutation and the stage of the disease (Table III). As regards the cytological method of tissue extraction, 5 (31\%) FNA samples among 16 were found positive for a $\mathrm{K}$-ras mutation while only 3 (14\%) among 21 bronchoscopy samples were positive for a K-ras mutation (Table IV).

\section{Discussion}

Activating mutations in the ras family genes represent a relatively common feature of lung tumours. We report that detection of activated ras alleles is possible in cytological

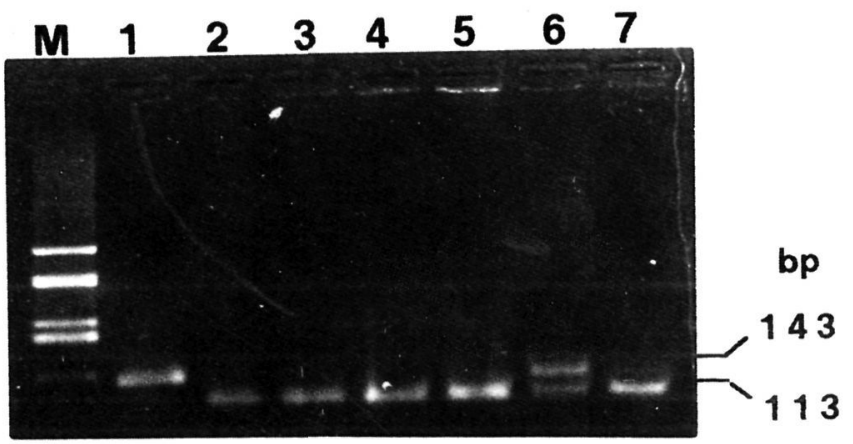

Figure 1. Detection of K-ras codon 12 point mutations by a combined PCRRFLP assay. Lane 1, DNA from the cell line SW 480 (mutant for K-ras codon 12); lanes 2-5, normal samples; lanes 6,7, samples with a mutation at $\mathrm{K}$-ras codon 12 ; M, pUC18/HaeIII.
Table I. Codon 12 point mutations in the ras family genes in 37 cytological specimens from patients with lung cancer.

Sample K-ras H-ras N-ras Cytology ${ }^{a}$ Stage Cytological No. method $^{b}$

\begin{tabular}{|c|c|c|c|c|c|c|}
\hline 1 & + & - & - & $\mathrm{SCC}$ & III & FNA \\
\hline 2 & - & - & - & SCC & III & B \\
\hline 3 & - & - & - & $\mathrm{SCC}$ & III & B \\
\hline 4 & - & - & - & $\mathrm{SCC}$ & I & B \\
\hline 5 & - & - & - & $\mathrm{SCC}$ & II & B \\
\hline 6 & - & - & - & $\mathrm{SCC}$ & III & B \\
\hline 7 & - & - & - & $\mathrm{SCC}$ & III & FNA \\
\hline 8 & - & - & - & $\mathrm{SCC}$ & I & B \\
\hline 9 & - & - & - & $\mathrm{SCC}$ & III & B \\
\hline 10 & - & - & - & $\mathrm{SCC}$ & III & B \\
\hline 11 & - & - & - & $\mathrm{SCC}$ & III & FNA \\
\hline 12 & - & - & - & $\mathrm{SCC}$ & II & B \\
\hline 13 & - & - & - & $\mathrm{SCC}$ & II & FNA \\
\hline 14 & + & - & - & $\mathrm{SCC}$ & I & FNA \\
\hline 15 & - & - & - & $\mathrm{SCC}$ & III & FNA \\
\hline 16 & - & - & - & $\mathrm{SCC}$ & III & B \\
\hline 17 & + & - & - & $\mathrm{SCC}$ & II & B \\
\hline 18 & - & - & - & $\mathrm{AC}$ & III & FNA \\
\hline 19 & - & - & - & $\mathrm{AC}$ & III & FNA \\
\hline 20 & - & - & - & $\mathrm{AC}$ & III & B \\
\hline 21 & + & - & - & $\mathrm{AC}$ & III & FNA \\
\hline 22 & - & - & - & $\mathrm{AC}$ & III & FNA \\
\hline 23 & - & - & - & $\mathrm{AC}$ & III & B \\
\hline 24 & - & - & - & $\mathrm{AC}$ & I & B \\
\hline 25 & - & - & - & $\mathrm{AC}$ & III & B \\
\hline 26 & - & - & - & $\mathrm{AC}$ & III & B \\
\hline 27 & + & - & - & $\mathrm{AC}$ & III & FNA \\
\hline 28 & + & - & - & $\mathrm{AC}$ & III & B \\
\hline 29 & - & - & - & small cell & III & FNA \\
\hline 30 & - & - & - & small cell & III & FNA \\
\hline 31 & - & - & - & small cell & III & FNA \\
\hline 32 & - & - & - & small cell & III & FNA \\
\hline 33 & - & - & - & small cell & I & B \\
\hline 34 & - & - & - & small cell & II & B \\
\hline 35 & - & - & - & small cell & II & B \\
\hline 36 & + & - & - & small cell & III & B \\
\hline 37 & + & - & - & $\begin{array}{l}\text { Hodgkin's } \\
\text { lymphoma }\end{array}$ & II & FNA \\
\hline
\end{tabular}

${ }^{\mathrm{a}} \mathrm{AC}$, adenocarcinoma; SCC, squamous cell carcinoma. ${ }^{\mathrm{b}} \mathrm{B}$, bronchoscopy; FNA, fine needle aspiration.

material from patients with lung cancer. This could be of considerable importance in the clinical practice because the presence of mutant ras alleles is associated with poor prognosis in lung tumours (4-8).

The higher incidence of ras mutations was found in adenocarcinomas $(3 / 11,27 \%)$. Significant incidence of mutations was also found in SCC (3/17, 18\%). Although the incidence of mutations reported in this study is lower than those reported by other investigators, generally our data are in agreement with previous findings. Suzuki et al (5) and 
Table II. K-ras codon 12 point mutations in association with the cytological diagnosis.

\begin{tabular}{lcc}
\hline Cytological type & No. of samples & K-ras mutations (\%) \\
\hline Adenocarcinoma & 11 & $3(27)$ \\
SCC $^{\text {a }}$ & 17 & $3(18)$ \\
Small cell & 8 & $1(13)$ \\
Hodgkin's lymphoma & 1 & 1 \\
Total & 37 & $8(22)$ \\
\hline
\end{tabular}

aSCC, squamous cell carcinoma.

Table III. K-ras codon 12 point mutations in association with the stage of the disease.

\begin{tabular}{lcc}
\hline Stage & No. of samples & K-ras mutations (\%) \\
\hline Stage I+II & 12 & $3(25)$ \\
Stage III & 25 & $5(20)$ \\
\hline
\end{tabular}

Table IV. Codon 12 point mutations in the K-ras gene in association with the cytological method.

Cytological method No. of samples K-ras mutations (\%)

\begin{tabular}{lll}
\hline FNA $^{\mathrm{a}}$ & 16 & $5(31)$ \\
Bronchoscopy & 21 & $3(14)$ \\
\hline
\end{tabular}

${ }^{\mathrm{a}} \mathrm{FNA}$, fine needle aspiration.

Rodenhuis and Slebos (8) detected mutations at K-ras codon 12 in approximately $30 \%$ of lung tumours, while the incidence of $\mathrm{H}$-ras and $\mathrm{N}$-ras point mutations was limited to $1.5 \%$ and $4.5 \%$ respectively. The majority of the mutations were found in adenocarcinomas, however, activating mutations were also detected in large cell carcinomas (LCC, $14 \%$ ) and SCC (5.5\%) (5). The high incidence of K-ras mutations in adenocarcinomas as compared to other histological entities of lung tumours (such as LCC and SCC), was not confirmed by a Spanish group (11) who demonstrated the presence of activating mutations of the K-ras gene in $21 \%$ of the SCC, while in adenocarcinomas the incidence of mutations was $14 \%$ of the specimens. The discrepancy may be due to the different epidemiological factors and is common to studies on the ras genes $(9,12)$.

A major problem in the detection of mutant ras alleles in cytological material is the presence of DNA from the adjacent normal tissue, in significant ratio as compared to the DNA from the tumour cells. In the case of FNA, normal DNA is derived from the peripheral blood which is present during the aspiration, while in the case of bronchoscopy normal epithelial cells may be present. In the case of a heterozygous mutation, a ratio of $1: 1$ between tumour versus normal cells results in a ratio of $1: 3$ between mutant versus normal ras alleles. In this case, a competition occurs during the in vitro amplification reaction, which results in significant decrease of the signal derived by the mutant allele. This may explain the slightly lower incidence of mutations reported in our study, as compared to that reported by others. However, the present study indicates that the detection of mutant K-ras alleles is possible in DNA extracted from cytological material and can be successfully applied in the clinical practice, at least in a subset of cases. Most of the mutations (Table IV) were detected in the FNA material, indicating that this is the more suitable technique for the detection of ras mutations.

Future investigations, aiming to increase the specificity of the cytological techniques and the sensitivity of the PCR amplification should be performed in order to make possible the application of molecular techniques in routine clinical practice.

\section{References}

1. Spandidos DA: A unified theory for the development of cancer. Biosci Rep 6: 691-708, 1986.

2. Spandidos DA (ed): Ras oncogenes. Plenum Press, New York, London pp1-323, 1989.

3. Bos JL: ras oncogenes in human cancer (review). Cancer Res 49: 4682-4689, 1989

4. Rodenhuis $\mathrm{S}$ and Slebos RJ: The ras oncogenes in human lung cancer. Am Rev Respir Dis 142: 27-30, 1990.

5. Suzuki Y, Orita M, Shiraishi M, Hayashi K and Sekiya T: Detection of ras gene mutations in human lung cancers by single-strand conformation polymorphism analysis of polymerase chain reaction products. Oncogene 5: 1037-1043, 1990.

6. Kratzke RA, Shimizu E and Kaye FJ: Oncogenes in human lung cancer. Cancer Treat Res 63: 61-85, 1992.

7. Slebos RJ and Rodenhuis S: The ras gene family in human nonsmall cell lung cancer. Monogr Natl Cancer Inst 13: 23-29, 1992.

8. Rodenhuis $\mathrm{S}$ and Slebos RJ: Clinical significance of ras oncogene activation in human lung cancer. Cancer Res 53 (Suppl): 2665-2669, 1992.

9. Kiaris H, Eliopoulos AG, Sivridis E, Ergazaki M and Spandidos DA: Activating mutations of ras family genes in prostatic cancer. Oncol Rep 2: 427-430, 1995.

10. Kiaris H and Spandidos DA: Analysis of H-ras, K-ras and Nras genes for expression, mutations and amplification in laryngeal tumours. Int J Oncol 7: 75-80, 1995.

11. Rosell R, Li S, Skacel Z, Mate J-L, Maestre J, Canela M, Tolosa E, Armengol P, Barnadas A and Ariza A: Prognostic impact of mutated K-ras gene in surgically resected non-small cell lung cancer patients. Oncogene 8: 2407-2412, 1993.

12. Saranath D, Chang SE, Bhoite LT, Panchal RG, Kerr IB, Mehta AR, Johnson NW and Deo MG: High frequency of mutation in codon 12 and 61 of H-ras oncogene in chewing tobacco-related human oral carcinoma in India. Br J Cancer 63: 573-578, 1991. 